\title{
THE SIGNIFICANCE OF EXECUTIVES IN CONNECTION WITH THE AGREEMENTS RESTRICTING ECONOMIC COMPETITION
}

\author{
JUDIT BARTA*
}

\begin{abstract}
The essay analyzes the agreements restricting economic competition focusing on leaders (executive officers and senior management employees). What are the roles of leaders in the infringements committed by the companies, is their behaviour directly evaluated by the laws and legal practice and how will their personal responsibility develop? The research concentrates on the Hungarian case law, only looking at cases in the European Union law where there are no Hungarian results.
\end{abstract}

Keywords: competition control proceedings, impose, executive officers, senior management employees, sanction, impeachment, notice of fines, cartel meetings, administrative penalty

\section{THE “CARTEL MEETINGS" AND THE MANAGEMENT}

The Chapter IV of the Act LVII of 1996 on the Prohibition of Unfair and Restrictive Market Practices (hereinafter Tpvt.) is about the prohibition of agreements restricting economic competition of which the definition is stated in the Section 11(1) article (hereinafter: cartel):

Agreements and concerted practices between companies, as well as the decisions of the organizations of companies established based on the right of association, their public bodies, associations and other similar (hereinafter referred to collectively as "association of companies") (hereinafter referred to collectively as "agreements"), which are aimed at the prevention, restriction or distortion of economic competition, or which may display or in fact displays such an effect, are prohibited.

The take-off of the fair and the lawful competition between companies is that their decisions should be made individually. The condition excludes any direct or indirect connection between competitors, regarding their market behaviour. ${ }^{1}$ It should be noted that not every connection is prohibited only those with a negative impact on the economic competition. Cartels are materialized in the forms of agreements and co-acting between companies, therefore the role of the management rather comes to the front.

* $\mathrm{PhD}$ senior lecturer, associate professor University of Miskolc, Faculty of Law, Institute of Civil Law Studies, Department of Commercial Law, associate professor University of National Public Services, Faculty of Public Governance and International Studies, Department of Civilistics.

Translater: Dr. Zita Nyikes PhD student, University of Miskolc, Ferenc Deák Doctoral School of Law.

1 Metropolitan Regional Court, case number 2.Kf. 27.052/2007/22.; 138/2002. VJ. 
According to experience, most agreements and co-acting restricting economic competition are made at different meetings. In case of smaller businesses executive officers, in case of bigger more structured enterprises senior management employees, rarely executive officers, take part in the meetings. Hungarian cartels are characteristically organised by the presence of the executive officers. Therefore, it is worth having a look at the forming practice of the law, regarding the role of the executive officers in the cases of infringements as well as their presence at the meetings.

Based on the coherent competition practice of the law, the enterprise taking part in the meeting should prove that its presence in the meeting later considered unlawful was not against the competition. What is more, the enterprise clearly has to distance itself from it, expressing its intention to the other distinctly. Excuses made by the company cannot be taken as aquittance such as:

- the executive officer was passive during the meeting ${ }^{2}$,

- the executive officer attended the meeting but left it, especially if there is an evidence that the person left the meeting not because of objecting but to avoid an inconvenient turn of the meeting,

- the senior management employee did not attend the meeting, but there is an evidence that another employee was present,

- the executive officer arrived at the end of the meeting only, not participating in the part where the company did not clearly distance itself from the unlawful action, ${ }^{3}$

- the enterprise stayed away from the meeting, but there is an evidence that it was informed about the meeting and it did not clearly distance itself from it expressing his intention to the other distinctly. ${ }^{4}$

Exceptional cases are when the executive officer does not take part in the cartel. In these cases the excuse for aquittance can be that the enterprise, its legal representative executive, its legal representative member did not know about the unlawful action. We can refer to the European Union court cases. The question is whether the company can be impeached if the executives were not aware of the violation of law.

The first court case relevant to the question above was the 7th June 1983 in Musique Diffusion française and Others v Commission (100/80-103/80, EU:C:1983:158). According to point 97, the enterprise can be found "guilty of infringement. For that the provision applies it is not necessary for there have been action by, or even knowledge on the part of, the partners or principal managers of the undertaking concerned; action by a person who is authorized to act on behalf of the undertaking suffices."

Furthermore, the points 25-28 of the judgement of the case 7th February 2013 (request for a preliminary ruling from the Najvyšší súd Slovenskej republiky [Slovakia]) — v Protimonopolný úrad Slovenskej republiky v Slovenská sporitel'ňa (C68/12, EU:C:2013:71) can provide further information. In the case, the Slovenská sporitel'na said that its employee who took part in the meeting of the represanatives

2 Case number 74/2003 VJ.

Case number 69/2008 VJ.

4 Case number 162/2004 VJ. 
of the banks had not been authorized to that effect. And it is not proved that the employee declared his consent to the conclusion of the meeting. ${ }^{5}$ The question was whether the Treaty on European Union and the Treaty on the Functioning of the European Union Article 101 Section 1 should be interpreted as meaning that, it is enough to declare unlawful action if the legal representative of the company or other representative personally agreed and there is evidence for the consent to the behaviour of the employee with no intention of clearly distancing from the unlawful behaviour.

According to the view of the Commission, the Treaty on European Union and the Treaty on the Functioning of the European Union Article 101 does not suggest neither the participation of the owner or the legal representative of the enterprise nor the awarness of it, but the participation of the person who is entitled to take action on behalf of the enterprise.

On the other hand, as it is emphasized by the Commission, the participation in prohibited cartel in terms of the Treaty on European Union and the Treaty on the Functioning of the European Union most of the time is a secret action which is not in accordance with formal requirements. It can rarely happen, that the representative of the company attends a meeting with the authorization to unlawful action.

The Treaty on the Functioning of the European Union Article 101 Section 1 should be understood that no prove of the consent and an authorization is needed from the executive officer for the existence of the agreements restricting economic competition.

In addition to the facts above, based on the court judgement the employee is delivering his duties under the authority and the interests of his employer. Therefore, the employee is considered as someone who is part of the unity of the economic entity (for further information: judgement in Becu and Others on 16 September 1999, C-22/98, EU:C:1999:419, point 26).

Consequently, due to the unified European Union case-law, an unlawful action against competition delivered by the employee is attributable to the economic entity which he belongs to. The company is responsible for its employee irrespective of whether the executive officers were aware of the infringement or were consent about it.

\section{LEGAL CONSEQUENCES OF THE AGREEMENTS RESTRICTING ECONOMIC COMPETITION}

There are several legal consequences of cartels: if it is formulated in a contract it should be considered against the law, and it is void and null. Compensation can be

5 Based on the permanent court judgements, if it is proven that an enterprise attended a cartel meeting, the duty to provide evidence of not performing unlawful action, not being aware of anything like that, having no intention of breaking the law, expressing clearly that it is not intended to take part in it is heavily weighed on the enterprise. It is a must that the enterprise must distance clearly from the unlawful action which can be seen explicitly for the other companies, or it has to report the unlawful initiative to the authorities. 
asked for the damage caused by the cartel against the company which is imposed by the authority. For cartels in public procurement criminal law sanctions and i.e. exclusions from further public procurement procedures must be taken into account.

The Hungarian competition law ${ }^{6}$ deals with the pursuits and functions of the enterprises, thus the behaviour and actions of the management and the employees are part of the economic entity. Most of the consequences are weighed on the enterprise, exceptionally executive officers have criminal law responsibitlity in cases of cartels in public procurement.

Naturally, the enterrpise has the opportunity to shift off the penalty and the fines towards those who are responsible for the action personally. For the damage caused by the executive officer i.e. administrative penalty the legal entity enterprise can assert a claim against the executive officer. In cases of executive officers Act V of 2013 on the Civil Code (hereinafter: Civil Code) must be applied ${ }^{7}$, in cases of executive employees Act I of 2012 on the Labor Code (hereinafter: Labor Code) must be applied.

Regarding experiences, it rarely occurs that executives are sancitoned by the Civil Law, enterprises do not assert a claim against their management members but most of the contract is terminated.

Among the sanctions that can be imposed on the enterprise there is one, the fine, the measure of which takes into account the behaviours and the roles of the the executive officers and executive managers. The fine will be explained in more detail below.

According to the Tpvt., the Competent Competition Council may impose fines. The fine shall be a maximum of ten percent of the company's net turnover, or the net turnover of the group - of which the company penalized is identified in the decision as a member - for the financial year preceding the year when the decision was adopted. The fine imposed upon associations of companies shall be a maximum of ten percent of the previous financial year's net turnover of the member companies. As regards the association of companies, the financial liability of each company in respect of the payment of the fine shall not exceed ten percent of the net turnover for the financial year preceding the date of the decision. ${ }^{8}$ The Section in 78 (3) in the

6 Tpvt. 1 Section 1 (1) This Act shall apply to the conduct of natural and legal persons on the market, and - with the exception of the forms of conduct described in Chapter VI including the Hungarian branches of foreign-registered companies (hereinafter referred to collectively as "companies") displayed in the territory of Hungary, unless otherwise provided for by law. The market conduct displayed by companies abroad, other than the forms of conduct regulated in Chapters II and III if performed outside the European Economic Area, shall also fall under the scope of this Act, if the effect of such conduct may manifest itself within the territory of Hungary.

7 Civil Code. Section 3:24 [Liability of executive officers] (1) The executive officer shall be held liable for damages caused to the legal person resulting from his management activities in accordance with the provisions on liability for damages for loss caused by non-performance of an obligation.

8 Tpvt. Section 78 (1b). 
Tpvt. gives a list of examples related to the circumstances kept count of imposing the fine. ${ }^{9}$ However, other view-points are not excluded. Other aspects and further circumstances that can be taken into account are detailed in the 1/2020 communication statement (hereinafter: Fine statement) of the Hungarian Competition Authority (hereinafter: GVH) by the chairman of the GVH Competent Competition Council employed since 1st January 2021.

\section{Behaviours of the executives, regarding the measure of the fine}

There may be several aggravating aspects during the imposition of the fine, of which one is the liability. Based on the Fine statement Point 13, deliberate unlawful action is considered the high level of liability, which can appear from the side of the executives. ${ }^{10}$ Liability is presumptive if it occurs during the public procurement. Sensible and transparent utilization of public money is well-known of which the executive must be aware of. ${ }^{11}$ Deliberateness is suggested if the unlawful action occurs either during the procuration tender financed from public money ${ }^{12}$ or during the collusion of the tender co-financed by the European Union, what is more, if the enterprise takes measures to keep the unlawful action as a secret.

Higher level of liability is based on the participation of the executive officers because they are expected to be more aware of any infringement. ${ }^{13}$

The Fine statement suggests fine reducing aspects such as different forms of cooperation from the enterprise i.e. participation in compliance policy, settlement procedures and other forms of cooperation.

The measure of the fine can be reduced by the settlement procedure during that the Competent Competition Council delivers the reduction of 10 to 30 percent of the fine. The compliance policy can result the reduction or the annullation of the fine. ${ }^{14}$

9 Tpvt. Section 78 (3) The fine shall be determined with regard to all applicable circumstances, in particular, to the gravity and duration of the infringement, the advantage gained by such conduct, the market position of the offenders, the degree of responsibility and any cooperation in the investigation, and repeated occurrence and frequency of the infringement. The gravity of the violation shall be determined, in particular, on the basis of the degree of obstructing competition and the scope and extent of the violation of the interests of final trading parties.

10 Case number 43/2015 VJ

11 For example case number 28/2003 VJ and case number 77/2016 VJ.

12 During a tender which does not reach the evaluation level of the procurement procedure, two contracting entities coordinate their offers. In the competition control procedure the executive of the business claimed that he was not aware of the infringement of the Tpvt. Section 11. The Competent Competition Council stated that the deliberateness is solid if the infringement is in context with tenders delaing with public money.(case number 19/2017. VJ).

13 There are several cases in which executives had direct participation in the infringement. The Competent Competition Council regarded these are aggravated aspects i.e. Case 6/2008 VJ; Case 43/2015 VJ; Case 19/2016 VJ; 19/2017 VJ.

14 Tptv. Section 78/A. 
According to Section 78/A the Competent Competition Council shall not impose, or shall reduce the fine in respect of a company that notifies the Gazdasági Versenyhivatal (Hungarian Competition Authority - GVH) - in accordance with this Act of any cartel constituting an infringement of Section 11 of this Act or Article 101 of TFEU or any agreement aiming, directly or indirectly, for fixing purchase or sale prices, or concerted practices (for the purposes of Sections 78/A-78/C hereinafter referred to as "infringement") and their participation therein.

The Competent Competition Council puts aside the fine only for that enterprise which is the first to apply and to provide evidence of the infringement giving base to execute an field investigation about the unlawful action, or the infringement can be proved unless the GVH has got sufficient amount of evidence backing the injuria.

In case the fine can not be annullated, the Competent Competition Council reduces the fine only if the enterprise provides such evidence to the GVH that has got extra value to the one that the GVH already has. The fine can be reduced to 50 percent based on the application aiming the reduced fine.

Whether the enterprise is taking part in settlement or compliance programe is mostly decided by the executives and depends on many factors. In Hungary, there are just a few applications for compliance programmes, and even fewer are those cases when the competition control procedure based on the applications for compliance i.e. one of the members of the cartel leaves the cartel ${ }^{15}$, or the enterprise is afraid of the public procurement contracting authority and the other independent contracting entity tends to report ${ }^{16}$. Most of the time enterprises tend to apply for compliance during the ongoing procedure.

There are other listed conditions of reducing or avoiding the fine based on the regulation of the Tpvt. ${ }^{17}$ Many of the conditions are related directly to the executive officers, and it also matters what managment decisions are made:

- the enterprise shall terminate any involvement it may have in the infringement immediately upon submission of the application, except where ordered by the $\mathrm{GVH}$ - by means of a ruling - to maintain such involvement to the extent and in the manner deemed essential to ensure the success of the competition control proceedings or the site search;

- the enterprise shall deliver a bona fide, permanent and covering all aspects cooperation until the completed competition control proceedings along with

15 In case of the so-called railways building cartel, there was a disagreement cumulated. The winning enterprise was not the one it planned to be during the public procurement procedure because another company enrolled for the project against the previous cartel agreement (Case number 174/2007 VJ).

16 In the case number 19/2017 VJ the proceeding started on the basis of the compliance application of the enterprise. The bidders had a cartel agreement. However, one of the cartel partners decided to step out of the cartel, therefore it applied for the compliance procedure.

17 Tpvt. Section 78/A (7). 
the GVH, which includes presence on hearing from the executive officers, employees, trustees or any kind member of effective management;

- the enterprise shall make executive officers, employees, delegates and other persons who effectively exercise control over the company available for interviews with the GVH and make reasonable efforts to make former executive officers, employees, delegates and other persons who effectively exercise control over the company available for interviews with the GVH;

- the enterprise shall avoid destroying, falsifying or concealing relevant information or evidence;

- the enterprise shall not disclose in any way or form without the express consent of the GVH that it has submitted an application for non-imposition of a fine and/or an application for reduction of a fine;

- the enterprise shall avoid destroying, falsifying or concealing relevant information or evidence even before it has submitted an application or revealing the application (before the GVH) publicly.

The strict regulation came into efect on the 1st January 2021. It is based on the Directive (EU) 2019/1 of the European Parliament and of the Council of 11th December 2018 to empower the competition authorities of the Member States to be more effective enforcers and to ensure the proper functioning of the internal market (hereinafter: Directive 2019/1 EU). ${ }^{18}$ Thus, the enterprise has to avoid destroying, falsifying or concealing relevant information or evidence even before it has submitted an application not just after the submission of the application in terms of the obligation of cooperation.

Inasmuch as the cooperation offered is suitable for both proceedings, the fine can be reduced contracted on both grounds. The maximum of 50 percent of reduction during the compliance proceeding and the reduction of 10 to 30 percent during the settlement proceeding can be summed up. Those enterprises which take part in the compliance proceedings can avoid the joint and several restitution liability, also the executive officers are not facing the criminal consequences.

In 2019 there were four cases which ended up with compliance proceedings. The Competent Competition Council reduced the fines for those enterprises involved by approximately 900 million HUF. ${ }^{19}$

In 2019 there were six cases of settlement proceedings during which the GVH reduced the fine imposed by approximately 850 million HUF. ${ }^{20}$

18 https://eur-lex.europa.eu/legal-content/HU/TXT/?qid=1601319436795\&uri=CELEX:32 019L0001.

19 In case number 10/2015 VJ about the check of the cash-register cartel, in case number 19/2016 VJ about the medical supplies, in case number 43/2015 VJ about the battery cartel, and the case number 103/2014 VJ. https://www.gvh.hu/pfile/file?path=/gvh/orszaggyulesi_beszamolok/gvh_ogy_pb_2019\&inline=true.

20 For example case number 97/2016 VJ, case number 41/2016 VJ, case number77/2016 VJ. https://www.gvh.hu/pfile/file?path=/gvh/orszaggyulesi_beszamolok/gvh_ogy_pb_ 2019\&inline=true. 
The executive officers can introduce compliance programmes in their companies that can help to avoid unlawful competitve actions, also they can encourage any action to be disclosed on time. The GVH takes the previous and the follow-up compliance efforts and programmes into account during the imposition of the fine. Extenuating circumstances are if high executive officers are no involved in the unlawful action.

Previous compliance programme can be taken into account by 7 percent when reducing of the fine. Inasmuch as the enterprise can provide evidence with further value, regarding the compliance programme, the allowance can go up to maximum 10 percent (Fine statement Point 30).

Undertaking of setting out and implementing the follow-up compliance programme, the GVH can offer the maximum of 5 percent, if the undertaking by the enterprise goes along with the participation in the compliance politics and settlement proceedings, etc. ${ }^{21}$

Beyond the evaluation of the compliance programme, the GVH takes it into account whether the executive officers are clearly, fully, publicly and definitely aware of the correspondance of the competition law (Fine statement Point 32 a).

The cooperation is an extenuating circumstance only if it serves the efficiency of the disclosure of the unlawful action e.g. willing to provide evindence about the violation of the law, clearing up the circumstances of the infringement, or not debating the facts (Fine statement Point 35). ${ }^{22}$ According to the Fine statement Point 34, it can result reducing the fine by 5 percent. A reduction can not be taken into account based on the declaration of the executive officer stating that further infringement in similar situation will be avoided (Fine statement Point 36). ${ }^{23}$

The compliance can not be called on if the executive officers delivered high level of infringement during the process of establishing the facts being disturbed. ${ }^{24}$

21 For example case number 77/2016 VJ.

22 In case number 74/2003 VJ the Competent Competitive Council declared that taking part in the compliance proceeding does not provide the basis of the reduction of fine unless the party provides further hels and assistance of disclosure of the infringement.

23 Fine statement Points 76-77.

24 See case number 111/2015 VJ. During the on-site inspection the manager-director of the company said that his laptom was not on him. However, his was carrying it in his backbag. During the inspection the backbag was checked. Another manager-director of another company was offering false cash registers to the inspectors. See furhter information in Point 5. http://nol.hu/gazdasag/eldugtak-laptopjaikat-a-rajtakapott-vallalkozok-1612335. Both manager-directors were purposeful to mislead the GVH inspectors and they wanted to hide evindence from the GVH. The GVH stated that destroying, falsifying or concealing relevant information or evidence is one of the most severe crimes to be commited. https://www.gvh.hu/sajtoszoba/sajtokozlemenyek/archiv/2016_os_sajtokozlemenyek/ maximalis_eljarasi_birsagokat_szabott_ki_a_gvh_a_h. 


\section{DIRECT CRIMINAL SANTION OF THE EXECUTIVE OFFICER}

One of the most severe cartel infringement occurs if the tenderers form a cartel during the public procurement procedure, divide the market shares or establish the prices. ${ }^{25}$

In 2019,60 to 65 percent of the cartel notices to the GVH were related to public procurement. The 70 percent of the notices arrived to the GVH were contracting notice based on the Act CXLIII of 2015 on public procurement. ${ }^{26}$ In these cases the contracting party indicated the infringement of the possibility of the cartelling of the tenders during the public procurement proceeding. ${ }^{27}$

Establishing a ciminal sanction is a way of restraining cartelization during the public procurement proceeding. The valid Act $C$ of 2012 on the Criminal Code also sanctions this kind of unlawful actions through the offense of "An agreement restricting competition in a public procurement and concession procedure". ${ }^{28}$ The perpetrator of this crime is not an enterprisse but the natural person within the company such as a member or the executive officer, etc., therefore the punishment is imposed directly on the unlawful actors. This research does not go into deeper analysis of the offense because there are several academic researches already dealing with this topic.

Based on Act C of 2012 on the Criminal Code Section 420 (5) the perpetrator of a criminal offence shall not be liable to punishment, based on (6) punishment may be reduced without limitation or, in cases deserving special consideration, dispensed with regarding a person who at the time of commissio was an executive officer, member, supervisory board member or employee of an undertaking, or an agent of any such person, who filed an application serving as ground for the non-application of a fine under the Act on the prohibition of restrictive market practices concerning the act, and revealed the circumstances of commission. Not only the successful compliance application is needed for the punishment to be avoided or specially considered but the perpetrator has to reveal the circumstances of the action committed.

25 For example cases number VJ-56/2004; VJ-48/2013; Vj-74/2004; Vj-27/2003; Vj97/2006; 134/2008 VJ; 111/2015 VJ; 77/2016 VJ; 19/2016 VJ.

26 Based on Act CXLIII of 2015 on public procurement Section 36 (2) if the contracting authority detects or has reason to suspect that the provisions of section 11 of Act LVII of 1996 on the prohibition of unfair and restrictive market practices (hereinafter "the Tpvt.") or the provisions of Article 11 TFEU have clearly been violated during the public procurement procedure, it shall notify the Hungarian Competition Authority (GVH) in line with the provisions laid down in the Tpvt. concerning notifications and complaints.

27 https://gvh.hu/pfile/file?path=/gvh/orszaggyulesi_beszamolok/gvh_ogy_pb_2019\&inline $=$ true.

28 Based on Act C of 2012 on the Criminal Code Section 420 (1) a person who restricts competition by entering into an agreement on fixing prices, fees or other contract terms, or dividing the market or engaging in any other concerted practice to influence the result of a public procurement procedure or an open or restricted tender published concerning an activity subject to a concession is guilty of a felony and shall be punished by imprisonment for one to five years. 
Paragraph (4) provides that the perpetrator of a criminal offence shall not be punsihed if he notifies the authorities proceeding in criminal matters of the act and reveals the circumstances of its commission before the authorities become aware of them.

It is very difficult to unreveal the crime. Mostly, the offenced competitors litigate but there are cases where the contracting entities took the cases to the court. It should be noted that there are no public court judgements on such cases, nor academic researches approaching this matter from the theoretical side, therefore there is no practical experience for the time being. There are a few newspaper articles that mention that there have been prosecution cases based on this criminal offence. ${ }^{29}$ The cases could not lead to charges in criminal proceedings due to compliance policy, the difficulty of providing evidence, the lack of the knowledge of competition law and the economic expertise of the investigating authorities.

\section{SANCTION OF THE BEHAVIOUR DURING THE COMPETITION CONTROL PROCEEDING}

The responsibility of executives during the competion control proceeding can be established and directly santioned by the mean of the administrative penatly. The penatly can only be imposed upon the executives if they engage in such an act or behaviour during the competion control proceeding which is either aimed at delaying, falsifying or concealing relevant information or evidence, or the result of which can breach the commitment through their own faults. ${ }^{30}$

A few of the instructive cases among the ones available for the public are listed below.

29 For further information, see case number 28/2013 VJ: competition control proceeding reveals the fact that prosecution was on-going. The salt dispersal cartel case: an undersecretary from an related Hungarian ministry reported the case. In 2013 a secret investigation started. Based on the bill, the perpetrators divided the market between them, and agreed on who is going to go for the call of the project and who is going to be the winner on which public procurement proceeding. The court found the perpetrators guily of the crime in its judgement on 22nd September 2020. The punishment was almost 25 millions HUF for 11 representatives of 7 enterprises. https://hvg.hu/gazdasag/20201002_kartell. https://infostart.hu/bunugyek/2020/09/22/kemenyen-buntette-a-irosag-a-soszoro-kartellugy-vadlottjait.

https://fovarositorvenyszek.birosag.hu/sites/default/files/field_attachment/200922_elsofoku_itelet_koncesszios_eljaras_buntette_miatt.pdf.

Investigation started in the so-called medical cartel, case number 19/2016 VJ. In this competition control proceeding many applied with compliance proceeding to the GVH. Three of the four applications were approved by the GVH. There is no further information about the criminal aspect of the case.

https://hvg.hu/kkv/20200116_Megerositette_az_ugyeszseg_nyomoznak_a_magyarorszagi_egeszsegugyi_kartell_ugyeben.

30 Tpvt. Section 61 (1). 
The GVH called the executives from each enterprise to testimony, declaration of evidence and client hearing in the case number 28/2013 VJ. Two executives refused to testify as witnesses, and in the third case the executive officer as the legal representative who was called as a client to the hearing did not appear. All the three executives called an excuse that there was an ongoing criminal procedure in parallel, and their testimony would be served as an evidence for their culpability, thus they would accuse themselves of committing crimes. The investigator imposed upon all the three executives fines because it was stated that the behaviours mentioned above served to conceal relevant information or evidence.

All the three executives appealed against the decisions imposing the fine (VJ28/2013.174; VJ-28/2013.175; VJ-28/2013.176). The Competent Competition Council gave approval of the previous decision confirming the established reasonings:

The witness can refuse answering questions if and only if he would accuse himself or his close relative of committing crime. Obviously, the witness is not in the position before the question articulated to decide whether he is entitled to answer, thus he does not have the opportunity to refuse testifying as a whole. Executives took the decisions of the Competent Competition Council to the court. The decrees were approved of the court.

The Competent Competition Council imposed fine in its number 32 decision in case number VJ-111/2015 because one of the executives tried to mislead the authority.

Field investigation was about to deliver by the GVH on the site of the enterprise but it was not successful due to many causes. The executive manager became aware of it.

During the repeated field investigation the executive manager gave a computer to the investigators claiming that he was working on it. The investigation revealed that there had been data modification on the computer, most of the data was destroyed by a new operation system being installed. Six weeks later investigators appeared for another on-site field investigation and they found out that the executive manager used another computer which was taken a mirror copy of. This copy showed a lot of years-old documents which were relevant during the proceeding.

It was confirmed that the behaviour of the executive manager was to falsify or conceal relevant information or evidence.

\section{SUMMARY}

The active and passive involvement of the executives is rather frequent. However, their direct impeachment is uncommon.

The legal regulations and legal case law concentrates on the role and the behaviour of the executives which is taken heavily into account during the fine imposition.

The infrigement of the executives during the competion control proceeding can be sanctioned by penatly. In other cases, personal conduct of the executive is relevant only in the public procurement cases. The criminal cases including accusations, and court judgements are rare in Hungary. 
There is no public law impeachment i.e. fine or banning related directly to the executives of the enterprises in Hungary.

However, the demand of the public law impeachment appeared in the references especially in those case where the enterprises commited cartelling as infringements. In the Hungarian law there are a few cases where the executive is responsible directly. In most cases, the restraining force is weak based on different reasons. However, the personal cartel liability would start the process of socialization and the trend of law-abiding attitude. Certainly, the compliance policy should be taken into account during the fine directly imposed on the executives. 